\title{
The hemostatic efficacy of hydrogen peroxide in adenoidectomy
}

\author{
Adenoidektomide hidrojen peroksitin hemostatik etkinliği
}

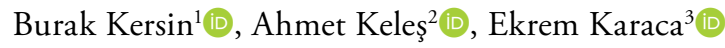 \\ ${ }^{1}$ Department of Otolaryngology, Kartal Dr. Lütfi Kırdar City Hospital, Istanbul, Turkey \\ ${ }^{2}$ Private Practice, Istanbul, Turkey \\ ${ }^{3}$ Department of Otolaryngology, Istanbul Medipol University, Istanbul, Turkey
}

\begin{abstract}
Objectives: This study aimed to investigate the effect of hydrogen peroxide, on the extent of intraoperative bleeding and operation times in pediatric patients undergoing adenoidectomy.

Patients and Methods: Data of 86 adenoidectomy patients ( 47 males, 39 females; mean age $5.2 \pm 1.9$ years; range 3 to 11 years) collected from patient files were retrospectively evaluated. The patients' age, sex, and adenoid tissue size, as well as anesthetic technique, operation time, amount of bleeding during the operation, were reviewed. Among the patients, 45 were administered hydrogen peroxide for hemostasis (study group) and 41 patients were not administered hydrogen peroxide during operation (control group).
\end{abstract}

Results: No statistically significant difference was found between groups in terms of age, sex and, adenoid tissue size $(p>0.05)$. The operation times of the study group were significantly lower than those of the control group $(\mathrm{p}=0.001 ; \mathrm{p}<0.01)$. There was also a statistically significant difference between groups in terms of bleeding amount $(\mathrm{p}=0.001 ; \mathrm{p}<0.01)$. Bleeding amount was significantly lower in the study group than in the control group.

Conclusion: In this study, we determined that administration of hydrogen peroxide with nasopharyngeal packing significantly decreases operation time and intraoperative bleeding in adenoidectomy patients.

Keywords: Adenoidectomy, hemostasis, hydrogen peroxide, intraoperative bleeding.
$\ddot{O} Z$

Amaç: Bu çalışmada, adenoidektomi uygulanan pediatrik hastalarda hidrojen peroksitin ameliyat sırasındaki kanamanın boyutuna ve ameliyat sürelerine etkisi araştırıldı.

Hastalar ve Yöntemler: Seksen altı adenoidektomi hastasının (47 erkek, 39 kadın; ort yaş: 5.2+1.9 yıl; dağılım, 3-11 yıl) hasta dosyalarından elde edilen veriler geriye dönük olarak incelendi. Hastaların yaşı, cinsiyeti ve adenoid dokusu boyutu ile anestezi tekniği, ameliyat süresi, ameliyat sırasındaki kanama miktarı gözden geçirildi. Hastalardan 45'ine hemostaz için hidrojen peroksit (çalışma grubu) kullanıldı, 41 hastaya ameliyat sırasında hidrojen peroksit kullanılmadı (kontrol grubu).

Bulgular: Gruplar arasında yaş, cinsiyet ve adenoid doku büyüklüğü açısından istatistiksel olarak anlamlı fark bulunmadı ( $>$ >0.05). Çalışma grubunun ameliyat süreleri kontrol grubuna kıyasla anlamlı olarak daha düşüktü $(\mathrm{p}=0.001 ; \mathrm{p}<0.01)$. Kanama miktarı açısından da gruplar arasında istatistiksel olarak anlamlı fark vardı $(\mathrm{p}=0.001 ; \mathrm{p}<0.01)$. Çalışma grubundaki kanama miktarı, kontrol grubuna kıyasla anlamlı derecede düşüktü.

Sonuç: Bu çalışmada, hidrojen peroksitin nazofarengeal tampon ile uygulanmasının adenoidektomi uygulanan hastalarda ameliyat süresini ve ameliyat sırası kanamayı önemli ölçüde azalttığı belirlendi.

Anahtar sözcükler: Adenoidektomi, hemostaz, hidrojen peroksit, ameliyat sırası kanama. 
Pediatric adenoidectomy continues to be among the most common pediatric surgical procedures. Although Guggenheim ${ }^{[1]}$ described a technique of direct adenoidectomy in 1957, the most commonly used technique today remains an essentially blind procedure using La Force or Beckman adenotomes. ${ }^{[1]}$ During this procedure, the surgeon relies on palpation or sometimes mirror examination to assess the adenoid tissue. ${ }^{[2]}$ Afterward, hemostasis is achieved by applying pressure with postnasal nasopharyngeal packing or irrigation with saline solutions.

Various adenoidectomy techniques have been described. Although curette adenoidectomy is the oldest method, it is still the most frequently used worldwide. A gauze tampon is frequently placed in the nasopharynx for hemostasis of the bleeding that occurs after adenoidectomy and is left in the nasopharynx for a duration. In the event that the hemorrhage cannot be controlled using this method, it is typically managed by other techniques, such as saline irrigation and epinephrine tampons or the use of cautery. ${ }^{[3-5]} \mathrm{An}$ advantage of using cautery is that it is cost effective. Its disadvantages include the risk of nasopharynx stenosis and the damage it can create in surrounding tissues. $^{[5]}$ Studies indicate that, on average, there is 43-54 $\mathrm{mL}$ of intraoperative hemorrhage during an adenoidectomy. If the hemorrhage exceeds $100 \mathrm{~mL}$, the risk of postoperative complications increases. ${ }^{[6]}$

Hydrogen peroxide is a colorless liquid with a bitter taste which dissolves in water to give an acidic solution. ${ }^{[7]}$ It is a strong oxidizing agent that produces free radicals, hydrogen peroxide anions, and reactive oxygen molecules. ${ }^{[8]}$ Hydrogen peroxide is routinely used by neurosurgeons as an aid to hemostasis after intracranial tissue resection. ${ }^{[9,10]}$ Hydrogen peroxide has also been used intraoperatively by surgeons in other tissues (breast, liver, etc.) to restrict tumor cells to the resection margin and to control bleeding. ${ }^{[11]}$

Del Principe et al. ${ }^{[12]}$ showed that collagen-induced platelet aggregation is associated with hydrogen peroxide release and that catalase inhibits both hydrogen peroxide formation and platelet aggregation. These studies suggest that hydrogen peroxide and oxygen free radicals have a role in the activation of platelets mediated by collagen. It has been proposed that oxidant species may behave as second messengers in stimulating cyclooxygenase-dependent and independent pathways of platelet activation. ${ }^{[12,13]}$

The aim of the present study was to investigate the efficiency of nasopharyngeal packing with hydrogen peroxide solution for the hemostasis after adenoidectomy.

\section{PATIENTS AND METHODS}

The retrospective study included 86 patients (47 males, 39 females; mean age $5.2 \pm 1.9$ years; range 3 to 11 years) who underwent adenoidectomy operations due to adenoid hypertrophy between January 1, 2016, and March 1, 2018. The patients were divided into two groups as study group $(n=45)$ and as control group $(\mathrm{n}=41)$. The patients' age, sex, and adenoid tissue size, operation time, and the amount of bleeding during surgery were determined from the patient files. A written informed consent was obtained from the patients in this study. The study was approved by the Local Ethics Committee of Istanbul Medipol University (Date/no: 16.04.2020/301). The study was conducted in accordance with the principals of the Declaration of Helsinki.

The indications for surgery were recorded as obstructive sleep apnea, snoring, nasal obstruction, and recurrent adenoiditis. Children who were operated by the same surgeon through cold dissection by curette were indiscriminately included in the study. Adenoid tissue was curetted. A gauze tampon with or without hydrogen peroxide was placed on the nasopharynx for $5 \mathrm{~min}$ to control bleeding. Data on the files were reviewed and recorded by an archiving officer, who was not informed about the aim of the study and the included groups. Intraoperative bleeding in the patients who underwent adenoidectomy in our hospital was determined by subtracting the amount of mouth rinsing fluid from the blood collected from the aspiration bag and assessed based on swab weights by precision scales. The data collected were recorded on the patients' files.

Patients who presented with bleeding diathesis, those older than 12 years and younger than three years, those with chronic metabolic diseases those that are syndromic, and patients that were operated with hot techniques during surgery or underwent another synchronous procedure in addition to adenoidectomy were excluded from the study.

All operations were performed under general anesthesia by the same otolaryngologist. After confirmation of endotracheal tube position, each patient was positioned supine in Rose position, and the neck was extended with a shoulder roll placed under the shoulders. The adenoidectomies were performed using adenoidectomy curettes. A Boyle-Davis gag was inserted. The palate was palpated to exclude a possible submucosal cleft. Adenoid tissue size was preoperatively assessed by flexible endoscopic examination and graded according to the four-level classification described by Clemens et al. ${ }^{[3]}$ This grading system is based on 


\begin{tabular}{|lccccc|}
\multicolumn{5}{c}{ Table 1} \\
\\
$\begin{array}{l}\text { Demographic data, surgical parameters } \\
\text { Age (year) }\end{array}$ & $\mathrm{n}$ & $\%$ & Mean \pm SD & Median & Min-Max \\
Sex & & & $5.2 \pm 1.9$ & 5.0 & $3.0-11.0$ \\
$\quad$ Female & 39 & 45.3 & & & \\
$\quad$ Male & 47 & 54.7 & & & \\
Adenoid tissue size & & & $3.1 \pm 0.8$ & 3.0 & $2.0-4.0$ \\
Amount of bleeding (mL) & & & $25.5 \pm 8.7$ & 22.0 & $13.0-45.0$ \\
Operation time (min) & & & $22.4 \pm 4.9$ & 22.0 & $13.0-39.0$ \\
\hline SD: Standard deviation. & & & & & \\
\hline
\end{tabular}

the degree of choanal obstruction caused by adenoids as follows: Grade 1, less than one-third of posterior choanae obstructed; Grade 2, one-third to two-thirds of posterior choanae obstructed; Grade 3, more than two-thirds of posterior choanae obstructed but not filling choanae; and Grade 4, complete choanal obstruction.

Complete removal of the adenoid tissue was confirmed by digital palpation and mirror examination. After adenoidectomy, two different methods were used to control bleeding: a gauze packing soaked in 3\% hydrogen peroxide was placed in the nasopharynx in the study group, while a gauze packing soaked in $0.9 \%$ physiological saline solution was used for the control group. Both were left in place for $5 \mathrm{~min}$. After tamponade, the nasopharynx was irrigated with saline solution at room temperature $\left(25^{\circ} \mathrm{C}\right)$. The irrigation was continued until the wash-out fluid was clear. The duration between application and removal of the mouth gag was accepted as the operation time.

\section{Statistical analysis}

The analysis was performed using IBM SPSS version 26.0 software (IBM Corp., Armonk, NY, USA).
The descriptive statistics were expressed as mean+ standard deviation, median (minimum-maximum), frequency, and ratio values. The distribution of variables was measured by the Kolmogorov-Smirnov test. Mann-Whitney $\mathrm{U}$ test was used in the analysis of quantitative independent data. Chi-square test was used in the analysis of qualitative independent data. In all analyses, a $p$ value of $<0.05$ was considered statistically significant.

\section{RESULTS}

Demographic characteristics of the patients are given in Table 1 . As indicated in Table 2, no statistically significant difference was found between groups in terms of age, sex, and adenoid tissue size ( $p>0.05$ ).

Mean operation times (the duration between application and removal of the mouth gag) were $18.9 \pm 2.7 \mathrm{~min}$ and $26.2 \pm 3.9 \mathrm{~min}$ in the study and control groups, respectively (Figure 1 and Table 2). The difference was highly statistically significant $(\mathrm{p}=0.001$; $\mathrm{p}<0.01)$. The mean amount of bleeding was $18.2 \pm 2.7$ $\mathrm{mL}$ in the study group and $33.5 \pm 5.3 \mathrm{~mL}$ in the control

\begin{tabular}{|c|c|c|c|c|c|c|c|c|c|}
\hline \multicolumn{10}{|c|}{ Table 2} \\
\hline & \multicolumn{4}{|c|}{ Control group } & \multicolumn{4}{|c|}{ Study group } & \multirow[b]{2}{*}{$p$} \\
\hline & $\mathrm{n}$ & $\%$ & Mean \pm SD & Median & $\mathrm{n}$ & $\%$ & Mean \pm SD & Median & \\
\hline Age (year) & & & $5.1 \pm 1.6$ & 5.0 & & & $5.2 \pm 2.1$ & 5.0 & $0.979^{*}$ \\
\hline Sex & & & & & & & & & $0.860 \dagger$ \\
\hline Female & 19 & 46.3 & & & 20 & 44.4 & & & \\
\hline Male & 22 & 53.7 & & & 25 & 55.6 & & & \\
\hline Adenoid tissue size & & & $3.0 \pm 0.8$ & 3.0 & & & $3.18 \pm 0.75$ & 3.0 & $0.344 *$ \\
\hline Amount of bleeding (mL) & & & $33.5 \pm 5.3$ & 33.0 & & & $18.2 \pm 2.7$ & 19.0 & $0.001 *$ \\
\hline Operation time (min) & & & $26.2 \pm 3.9$ & 26.0 & & & $18.9 \pm 2.7$ & 19.0 & $0.001 *$ \\
\hline
\end{tabular}




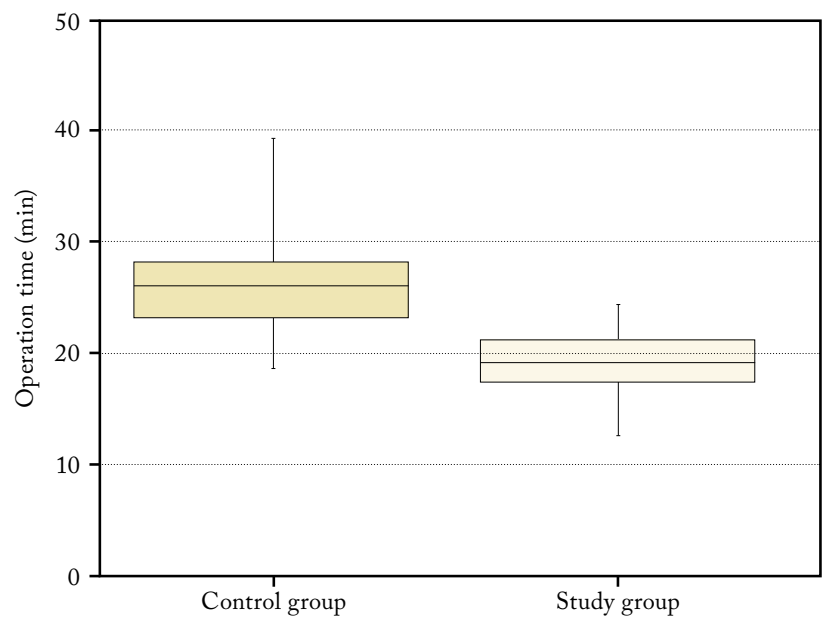

Figure 1. Comparison of the operation times of the groups.

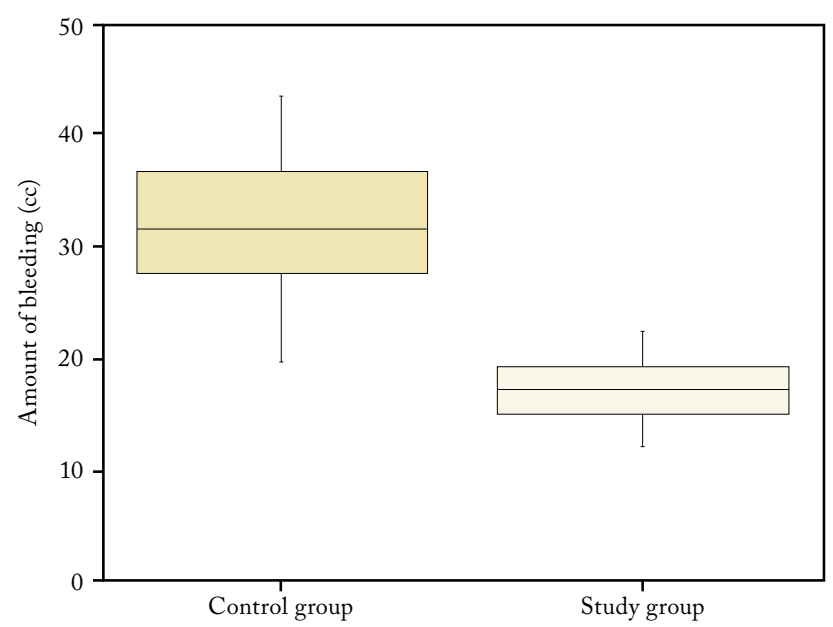

Figure 2. Comparison of the bleeding amounts of the groups.

group, with a highly statistically significant difference $(p=0.001 ; p<0.01)$ (Figure 2 and Table 2).

\section{DISCUSSION}

Numerous hemostatic agents have been studied for their effectiveness in reducing intraoperative bleeding in adenoidectomy. ${ }^{[14,15]}$ For example, Ankaferd Blood Stopper (Ankaferd Health Products Ltd., Istanbul, Turkey), topical use of tranexamic acid, FloSeal (sterile mixture of a gelatin matrix and thrombin), use of racemic adrenaline, and warm saline irrigation have favorable effects on operation time and bleeding control in adenoidectomy. ${ }^{[4-6,16,17]}$

The hemostatic effect of FloSeal in adenoidectomy was studied in 70 children. FloSeal applied as a gel to the nasopharynx region considerably reduced the time of hemostasis and amount of bleeding during operations. The mean hemostasis time and blood loss during hemostasis in the FloSeal group were $0.6 \mathrm{~min}$ and $2.5 \mathrm{~mL}$, respectively, and those of the cauterization group were $9.5 \mathrm{~min}$ and $29.4 \mathrm{~mL}$, respectively. ${ }^{[6]}$ Teppo et al. ${ }^{[5]}$ investigated the effectiveness of topical use of epinephrine in bleeding control during adenoidectomy in 93 children. The mean operation time in adenoidectomy was significantly reduced with the use of topical epinephrine as a hemostatic substance, with $18 \mathrm{~min}$ in the control group and $13 \mathrm{~min}$ in the study group. The effectiveness of warm $\left(50^{\circ} \mathrm{C}\right)$ saline solution irrigation for hemostasis in adenoidectomy was evaluated in 120 pediatric patients. ${ }^{[4]}$ The mean operation time was $12 \mathrm{~min}$, and the use of hot saline irrigation decreased operation time by $3.1 \mathrm{~min}$. Iynen et al. ${ }^{[18]}$ investigated the effect of the Ankaferd Blood Stopper on intraoperative hemorrhage in 46 children. Operation time was significantly decreased from $13 \mathrm{~min}$ to $9 \mathrm{~min}$, while hemostasis time decreased from $5.8 \mathrm{~min}$ to $3.8 \mathrm{~min}$. The hemostatic efficiency of the Ankaferd Blood Stopper in adenoidectomy appears to be proven with $20 \mathrm{~mL}$ average blood loss in the study group compared to the $25 \mathrm{~mL}$ in the control group. ${ }^{[16]}$

Four hundred children were included in a study investigating the use of tranexamic acid in adenoidectomy operation as reported by Albirmawy et al. ${ }^{[17]}$ The result of the topical use of tranexamic acid on operation duration and hemostasis time was not evaluated in their study; however, the level of blood loss during surgery and the frequency of primary postadenoidectomy hemorrhage were significantly reduced in children in the study group. Although effective in preventing excessive bleeding during adenoidectomy, all hemostatic agents mentioned above have some disadvantages. For instance, Floseal, the most effective hemostatic substance reported in studies, is expensive to use in adenoidectomy. Saline irrigation can be used to control bleeding during an adenoidectomy. However, the requirement of heating the saline solution to $50^{\circ} \mathrm{C}$ can cause problems during surgery when sudden maintenance is required to prevent excessive blood loss.

Ugur et al. ${ }^{[19]}$ studied the effectiveness of $0.5 \%$ hydrogen peroxide irrigation to control bleeding after adenoidectomy. They reported no statistical reductions in hemostasis or operative time in the $0.5 \%$ hydrogen peroxide group, although the average hemostasis time of the hydrogen peroxide group was shorter than that of the control group. In the literature, there are some cases demonstrating that the imprudent use of over-the-counter hydrogen peroxide can result in 
a chemical burn to the oral mucosa. ${ }^{[20,21]}$ Therefore, it is appropriate that products containing moderate concentrations of hydrogen peroxide $(>5 \%)$ carry warnings relating to avoiding both ingestion and contact of hydrogen peroxide solutions with the skin or mucosal surfaces. The hazard rating for contact with $3 \%$ hydrogen peroxide is rated as slight, whereas that for $30 \%$ hydrogen peroxide is rated as extreme because of the corrosive nature of potent hydrogen peroxide solutions. ${ }^{[21]}$

In our study, hydrogen peroxide (3\%) solution was used only for bleeding control with gauze, not for irrigation. Only physiological saline solution was used for irrigation. Thus, we have not observed any chemical burn in the oral cavity or oropharynx mucosa. During surgery, excess hydrogen peroxide leaking from the nasopharyngeal pack was immediately aspirated from the oral cavity to act only on the nasopharyngeal bleeding site. Topical use of a hemostatic agent is not always possible, particularly for surgical cuts with hard to expose bleeding foci. In such instances, administering a hemostatic agent with topical pressure is an effective method to stop hemorrhage. Therefore, within the present study, we evaluated the effectiveness of hydrogen peroxide for the control of intraoperative bleeding in pediatric adenoidectomy. Results indicated a significant decrease in both the amount of bleeding and operation times with hydrogen peroxide $(\mathrm{p}<0.001$ for both, Table 2) in the study group. Since hemostasis time is an indirect indicator of blood loss, we meticulously measured the amount and duration of bleeding during surgery.

The same surgeon performed all operations in order to eliminate the effect of the experience of the surgeon in the amount and duration of bleeding after adenoidectomy. In addition, an agreement between the raters was not required to evaluate the size of the adenoid.

However, there are limitations of this study. The patients were not followed long-term to evaluate the effects related to the use of hydrogen peroxide, and the number of patients evaluated could be considered few $(n=86)$, even though it was sufficient to prove statistically significant results of hydrogen peroxide administration in amount of bleeding and operation times. Further studies with a larger sample size on the efficacy of other newer adenoidectomy techniques are required to prove the efficacy of hydrogen peroxide administration in adenoidectomy.

In conclusion, we determined that the use of hydrogen peroxide-soaked packing considerably decreases the amount of intraoperative bleeding and operation times in adenoidectomy patients. Therefore, hydrogen peroxide can be beneficial during adenoidectomy to avoid associated side effects and blood loss and ensure a shorter operation time. The results of the study require verification from more comprehensive prospective studies.

\section{Declaration of conflicting interests}

The authors declared no conflicts of interest with respect to the authorship and/or publication of this article.

\section{Funding}

The authors received no financial support for the research and/or authorship of this article.

\section{REFERENCES}

1. Guggenheim P. Direct adenoidectomy. III. Results. AMA Arch Otolaryngol 1957;66:26-34.

2. Hartley BE, Papsin BC, Albert DM. Suction diathermy adenoidectomy. Clin Otolaryngol Allied Sci 1998;23:308-9.

3. Clemens J, McMurray JS, Willging JP. Electrocautery versus curette adenoidectomy: Comparison of postoperative results. Int J Pediatr Otorhinolaryngol 1998;43:115-22.

4. Ozmen S, Ozmen OA. Hot saline irrigation for control of intraoperative bleeding in adenoidectomy: A randomized controlled trial. Otolaryngol Head Neck Surg 2010;142:893-7.

5. Teppo H, Virkkunen H, Revonta M. Topical adrenaline in the control of intraoperative bleeding in adenoidectomy: A randomised, controlled trial. Clin Otolaryngol 2006;31:303-9.

6. Mathiasen RA, Cruz RM. Prospective, randomized, controlled clinical trial of a novel matrix hemostatic sealant in children undergoing adenoidectomy. Otolaryngol Head Neck Surg 2004;131:601-5.

7. Tredwin CJ, Naik S, Lewis NJ, Scully C. Hydrogen peroxide tooth-whitening (bleaching) products: Review of adverse effects and safety issues. Br Dent J 2006;200:371-6.

8. Dahl JE, Pallesen U. Tooth bleaching--a critical review of the biological aspects. Crit Rev Oral Biol Med 2003;14:292-304.

9. Epstein JA. Hydrogen peroxide for hemostasis. Neurosurgery 1987;20:63.

10. Mawk JR. Hydrogen peroxide for hemostasis. Neurosurgery 1986;18:827.

11. Mesiwala AH, Farrell L, Santiago P, Ghatan S, Silbergeld DL. The effects of hydrogen peroxide on brain and brain tumors. Surg Neurol 2003;59:398-407.

12. Del Principe D, Menichelli A, De Matteis W, Di Corpo ML, Di Giulio S, Finazzi-Agro A. Hydrogen peroxide has a role in the aggregation of human platelets. FEBS Lett 1985;185:142-6.

13. Iuliano L, Colavita AR, Leo R, Praticò D, Violi F. Oxygen free radicals and platelet activation. Free Radic Biol Med 1997;22:999-1006. 
14. Jo SH, Mathiasen RA, Gurushanthaiah D. Prospective, randomized, controlled trial of a hemostatic sealant in children undergoing adenotonsillectomy. Otolaryngol Head Neck Surg 2007;137:454-8.

15. Derkay CS, Baydoun HA, Stone L. Intraoperative use of QuikClot during adenotonsillectomy: A prospective pediatric trial. Ann Otol Rhinol Laryngol 2015;124:384-91.

16. Yasar H, Ozkul H. Haemostatic effect of Ankaferd Blood Stopper $\left({ }^{\circledR}\right)$ seen during adenoidectomy. Afr J Tradit Complement Altern Med 2011;8:444-6.

17. Albirmawy OA, Saafan ME, Shehata EM, Basuni AS, Eldaba AA. Topical application of tranexamic acid after adenoidectomy: A double-blind, prospective, randomized, controlled study. Int J Pediatr Otorhinolaryngol 2013;77:1139-42.
18. Iynen I, Bozkus F, San I, Alatas N. The hemostatic efficacy of Ankaferd Blood Stopper in adenoidectomy. Int J Pediatr Otorhinolaryngol 2011;75:1292-5.

19. Uğur KŞ, Ark N, Kurtaran H, Yüksel A, Kaya M, Gündüz $M$, et al. Hydrogen peroxide irrigation in children undergoing adenoidectomy: A preliminary study for hemostasis after surgery. KBB ve BBC Dergisi 2015;23:7-11.

20. Rostami AM, Brooks JK. Intraoral chemical burn from use of 3\% hydrogen peroxide. Gen Dent 2011;59:504-6.

21. Baker Chemicals. Hydrogen peroxide (3\%) Material Safety Data Sheet (SAF-T-DATA). Phillipsburg: Baker Chemicals; 1993. Available at: https://www.avantorinc. com/Proven-Brands/JTBaker.aspx. 